軽金属 第71巻 第6号 (2021), 264-268 DOI: 10.2464/jilm.71.264

(C) 2021 The Japan Institute of Light Metals

\title{
レーザ溶接によるアルミニウム合金と異種金属の接合 Joining of aluminum alloy and different metals by laser welding
}

\author{
泊 圭一郎**松本 剛
}

Keiichiro TOMARI* and Tsuyoshi MATSUMOTO

\section{1. はじめに}

近年の $\mathrm{CO}_{2}$ 削減要求の高まりを受け, 自動車を主とした輸 送機器の重量軽量化が活発に議論されており, 高張力鋼板 (ハイテン)，アルミニウム合金，マグネシウム合金，プラス チック・樹脂の適用が検討されている。ただし, 現状自動車 構造の主要材料である鋼をすべて代替することは, 製造面, コスト面での懸念が大きいことから, 最近では, 各種材料の 固有の特徵を活かして最大効果を発揮するべく，材料の適材 適所化が強く望まれている。

その達成のため, 「ハイブリッド構造」の検討, 例えば, 鋼と 軽量なアルミニウム合金との組合せによる異種金属接合もその 主要な解決策の一つであると考えられる。しかしながら, 異種 金属の溶融接合においては金属が相互溶融したときに生成する 脆い金属間化合物（Intermetallic Compound：以下 IMCと記す） を制御しなくてはならないという課題があり, 継手の品質改善 が検討されている。溶融接合法としてはアーク溶接, レーザ溶 接, 抵抗溶接があり, いずれの接合法も適用においては溶融部 組成と冷却速度の制御が重要とされる。本報では，それらの溶 融接合法の中の一つとして, 高エネルギー密度熱源によって金 属の急速加熱/凝固が期待できるレーザ溶接を用いた異種金属 の接合方法について検討された技術について調査を行った。

\section{2. レーザとその開発動向}

レーザ溶接 $\left(\right.$ 図 $1^{1)}$ ) は集光された数百 $\mathrm{kW} / \mathrm{cm}^{2}$ のパワー密 度を有するビーム光を照射することで, キーホール型溶融と なる溶接部を形成する。溶接用レーザとして, これまでに

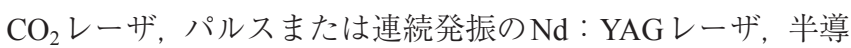
体レーザ，ディスクレーザ，ファイバーレーザなどが開発さ れ，ものづくりに活用されている。

まず高パワー化が容易で高速・深溶込み溶接が可能な $\mathrm{CO}_{2}$ レーザおよびファイバー伝送が可能で高柔軟性の YAGレー ザが開発され，自動車ルーフ，電装部品などの溶接に適用さ れてきた。続いて, ビーム光の集光性向上によってより安定 したビーム形成 (レーザの高品質化) が可能となり, 高パワー $\mathrm{CO}_{2}$ レーザおよび連続高パワーYAGレーザが開発され, 従来 のものの代用として用いられるだけでなく、リモート溶接用 にも利用されてきた。その後は, 電気一光変換効率が最も高
くてファイバー伝送が可能な高柔軟性の半導体レーザや $\mathrm{Yb}$ をドープしたレーザ媒質を用いる高輝度・高品質のファイ バーレーザおよびディスクレーザの開発が活発である。表 $1^{2)}$ にそれぞれのレーザの特徴を示している。

最近の半導体レーザは, ビーム品質が従来のYAGレーザと 同等のものや，ディスクレーザと同等レベルまで改善された ものが市販されるようになり，ブルーレーザ，グリーンレー ザのように高効率・高輝度な半導体レーザの高パワー化が競 われている。

また, 数 $\mathrm{kW}$ のフィバーレーザやディスクレーザでは溶 接中に大きなスパッタがときどき発生して, 溶接ビード表面 が荒れてピットが形成する場合がある。これらを改善する一 つの方法として，2重のファイバーを利用して細径の集光 ビームとその周囲のリング形状のパワー密度分布を有する ビームモード制御レーザが最近開発された。

現在, 高速・高生産性の接合方法として最も注目されるの がリモート（スキャナ）溶接である。スキャナ（ミラー）を 動かすリモート溶接では, レーザの加工点を瞬時に移動させ ることができ，機械動作（ロボット等）による移動のロスタ イムを画期的に削減することが可能となっている3)。

\section{3. レーザブレージング}

レーザブレージングとは熱源にレーザを用いるブレージン グ方法であり, 従来のろう付法と同様にろう材をあらかじめ ろう付部に設定してレーザを照射する「置きろう方式」と，

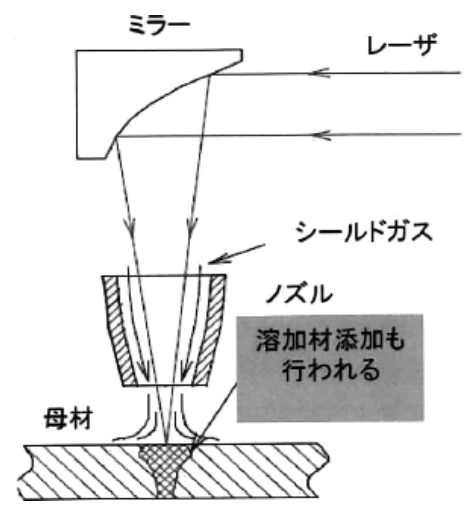

図1 レーザ溶接概念図 ${ }^{1)}$ 
||||||||||||||||||||||||||||||||||||||||||||||||||||||||||||||||||||||||||||||||||||||||||||||||||||||||||||||||||||||||||||||||||||||||||||||||||||||||||||||||||||||||||||||||||||||||||||||||||||||||||||||||||||||||||||||||||||||||||||||||||||||||||||||||||||||||||||||||||||||||||

表 1 溶接・接合用レーザの種類と特徴 ${ }^{2)}$

\begin{tabular}{|c|c|c|c|c|}
\hline 種類 & 波長（ $\mu \mathrm{m} ）$ & 発振効率（\%） & 出力 $[$ 連続 $](\mathrm{kW})$ & 利点 \\
\hline $\mathrm{CO}_{2}$ レーザ & 10.6 & 10 & $\begin{array}{c}\text { 最大 : } 50 \\
\text { 通常 : } 1 \sim 15\end{array}$ & 高出力化容易 \\
\hline YAGレーザ & 1.06 & $1 \sim 4$ & $\begin{array}{c}\text { 最大 : } 10 \\
\text { 通常 : } 0.05 \sim 7\end{array}$ & $\begin{array}{c}\text { ファイバー伝送可能, 波形制御, } \\
\text { 分岐可能, 高柔軟性 }\end{array}$ \\
\hline 半導体レーザ & $0.8 \sim 1.0$ & $20 \sim 50$ & $\begin{array}{c}\text { 最大 : } 15 \\
\text { 通常 : } 0.05 \sim 4\end{array}$ & コンパクト, 高効率 \\
\hline LD励起固体レーザ & 1.0 & $10 \sim 20$ & 最大：13.5 & ファイバー伝送, 高効率 \\
\hline ディスクレーザ & 1.03 & $15 \sim 25$ & $\begin{array}{c}\text { 最大 : } 16 \\
\text { 通常 : } 0.5 \sim 8\end{array}$ & ファイバー伝送可能, 高輝度, 高効率 \\
\hline ファイバーレーザ & 1.07 & $20 \sim 30$ & $\begin{array}{l}\text { 最大 : } 50 \\
\text { 通常 : } 0.2 \sim 10\end{array}$ & ファイバー伝送可能, 高輝度, 高効率 \\
\hline
\end{tabular}

図2 (a $)^{4)}$ に示すようにろう材を供給しながらレーザを照射す る「差しろう方式」がある。レーザブレージングは1980年代 に開発されたレーザはんだ付を応用させたプロセスとして位 置づけられるが，レーザ発振機の高出力化に伴い，融点の高 いろう材を用いる硬ろう付に適用されるようになった。レー ザブレージングの一般的な特徴としては(1)溶融溶接とろう付 の中間的な接合プロセス, (2)母材に対するぬれ性やエロー ジョンを高度に制御可能, (3)局所加熱, 急熱/急冷による母材 の材質劣化や変形抑制可能, (4)インプロセスモニタリングや リアルタイム制御可能, (5)万う付品質の安定化や高信頼化の 達成，などが挙げられる。アルミニウム合金および鋼のろう 付，さらにこれらの異材接合に対してレーザブレージングが 実用化されるに至っている。また近年, 予熱用としてレーザ 発振機を追加したタンデムレーザブレージング法も開発され ている(図2 $\left.(\mathrm{b})^{5)}\right)$ 。

\section{4. レーザ異材接合技術}

\section{1 異種材料のレーザブレージング}

異種材料のレーザ溶接では, 通常の溶接と同様に, 突合せ
部や重ね部において異材を共に大きく溶融させて混合させる と, 固液共存域が広い組成やIMCが生成する組成の領域が広 範囲に形成し, 高温割れが発生する。このため, 異材接合で は一方の材料を溶かし, 他の材料の溶融を抑制するような溶 接方法を採用することが重要である。また，レーザとしては 高輝度のレーザが一般的に有利であるが，アルミニウム合金 やマグネシウム合金などの薄板の溶接やろう付を利用する溶 接では, パワー密度があまり高くない条件で半導体レーザも 利用できる。特に, 薄板になると入熱の制御の点から他の熱 源が利用できなくなり, パルスレーザが有利になる。ただし， パルスレーザによる溶融溶接の場合, 急速凝固により溶接金 属部に凝固割れが起こりやすいので, 溶融金属の組成に注意 を払う必要がある6)。

YAGレーザまたは半導体レーザを用いて, 低炭素鋼と A6000系合金薄板の接合が試みられ，機械的特性の良好な継 手が得られたことが報告されている7)。YAGレーザによる接 合部の例を図 $3^{7)}$ に示す。レーザは主に鋼に照射され，その一 部が同時にアルミニウム合金に照射されるが, 鋼を溶融させ ない程度に加熱し, その熱と一部の照射レーザでアルミニウ (a)

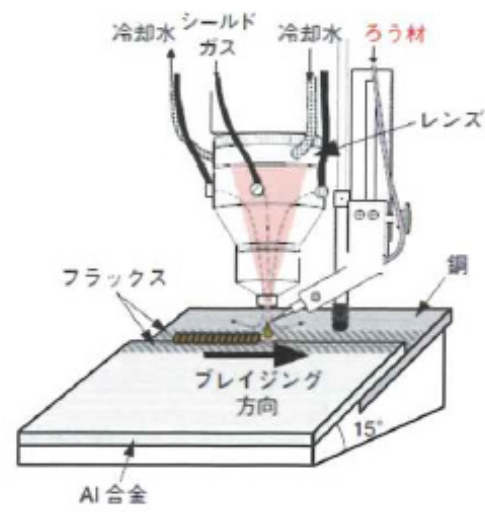

(b)

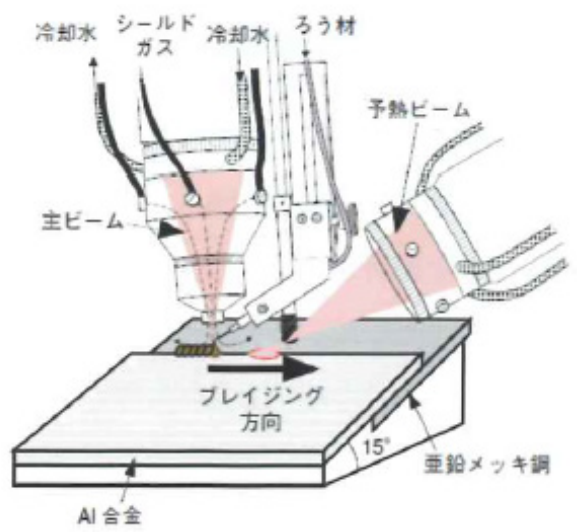

図2 異材接合のレーザブレージングの例

（a）シングルビームろう付 ${ }^{4)}$ ，（b）タンデムビームろう付 ${ }^{5)}$ 


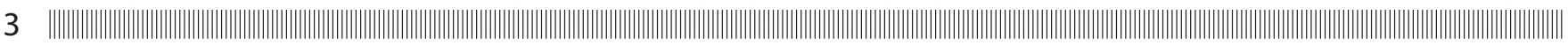

ム合金のみを溶融させる方法であり, IMC層を極めて薄くで きるという特徵がある。ただし，機械的特性の観点から IMC 層の厚さを $10 \mu \mathrm{m}$ 以下に抑制する必要があり，またアルミニ ウム合金の濡れをよくするためにフラックスを用いる必要が ある。

\section{2 インサート材を用いたレーザブレージング}

アルミニウム合金とマグネシウム合金の異材接合における 継手特性の向上には，母材同士の界面反応の抑制が重要であ ることが知られている。界面反応を制御する手法として，イ ンサート材を母材間に挟み，接合を行うことで母材同士の相 互拡散を抑制する手法がある。レーザブレージングにおいて もインサート材を母材間に挟み込むことで IMCの生成を抑 制することが期待されており，例としてチタン箔をインサー 卜材として適用した検討が報告されている。図4 $4^{8)}$ に示すよう に, Tiインサートを用いたA5052合金とAZ31合金のレーザブ レージングではAZ92ワイヤ/TiインサートおよびTiインサー 卜/A5052の接合界面部にて非常に薄いIMCが形成されるこ とで接合が達成されており, 直接接合と比較してTiインサー 卜を用いることで継手強度が著しく増加することが報告され ている ${ }^{8)}$ 。

\subsection{FCW を用いたレーザブレージング}

本項では，当社で取り組んだレーザブレージング関連技術 について紹介する ${ }^{9)}$

鋼材とアルミニウム合金材の異種金属接合において, 十分 な接合強度を確保するためには，接合界面に形成する Fe-Al 系の脆弱な IMC の成長を抑制する必要がある。過去の知見の 一つとして，ろう付用のアルミニウムフラックスコアードワ イヤ（以降 Al-FCW）を用いてレーザでのブレージング+溶 接（以降ブレーズ溶接）を施工することにより，脆弱な IMC

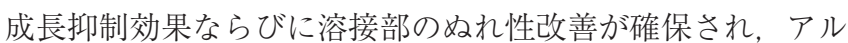
ミニウム合金材溶接継手の引張剪断強度となる継手性能が得 られていた。

しかし，ろう付用の Al-FCWの本ブレーズ溶接への適用は, ワイヤ送給時の座屈，スラグ過多，剥離強度が低いなど，実 用化には不適合な要素があった。当社では，それらを解決す るために，工業的な用途にも応えうる新しいAl-FCWの開発 に着手した。具体的には，Al-FCWの構成要素であるシース 材とフラックスについて適正化を図った。

シース材成分の適正化では, FCW 形態の簡易的模擬のた め, 当初はソリッドワイヤ形態とした。施工は, 一般的なろ う付用 $\mathrm{Al}-\mathrm{FCW}$ に適用される粉末状フラックスをあらかじめ
表面に塗布したアルミニウム合金材を上，鋼材を下に配置し て重ね合わせ，アルミニウム合金材の端部にレーザ光を照射 して溶融させ，その溶融部にソリッドワイヤを供給添加する
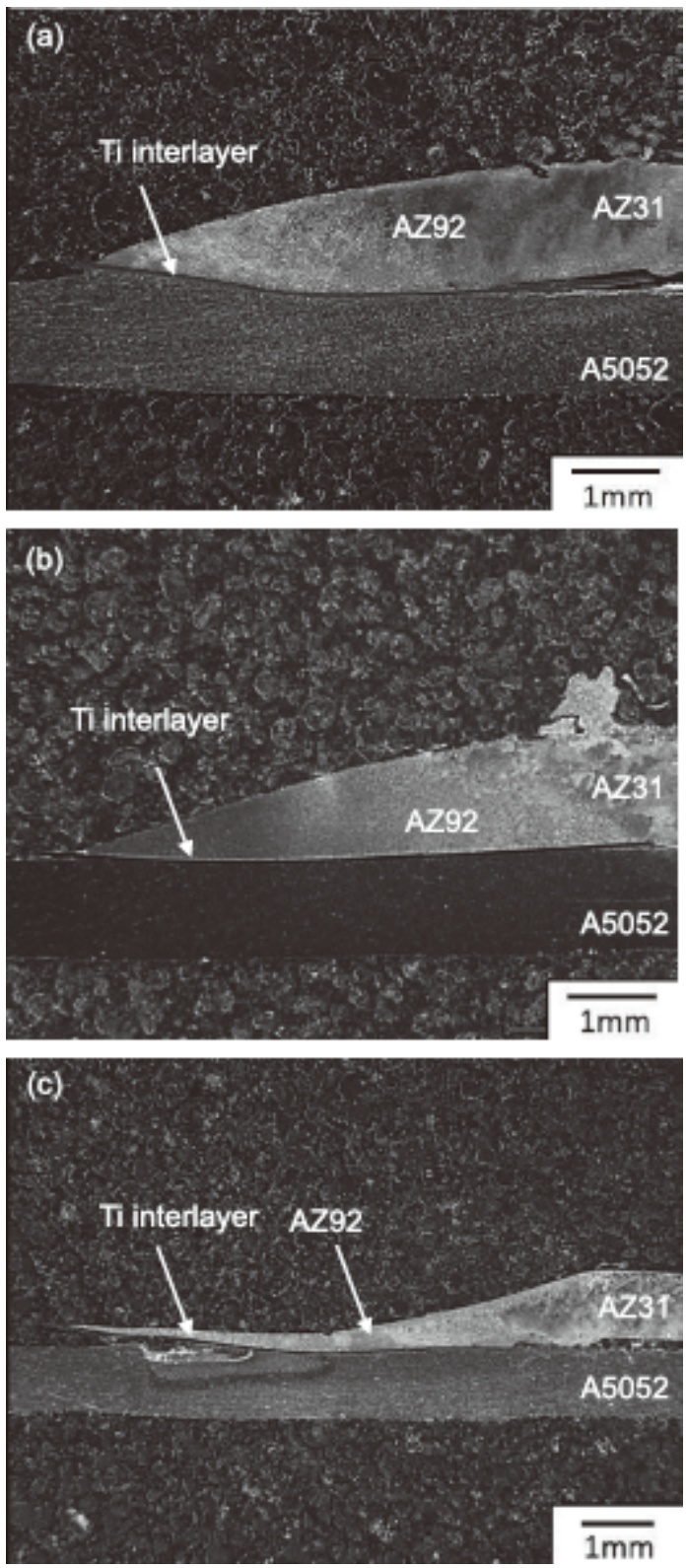

図4 レーザブレージングを用いたアルミニウム合金と マグネシウム合金の異材接合に及ぼす Tiインサー トの効果 ${ }^{8)}$

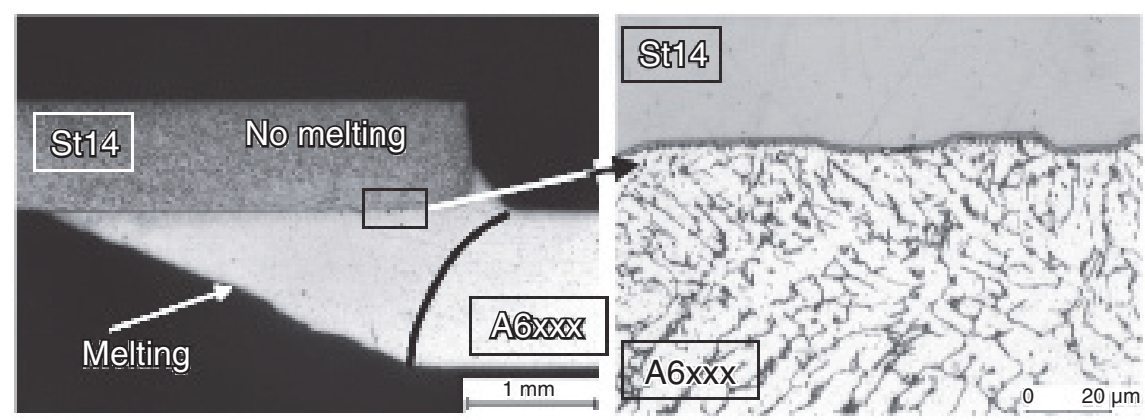

図3 低炭素鋼とA6000 系合金のYAG レーザ溶接断面 ${ }^{7}$ 
方法を用いて，重ねすみ肉溶接継手を作製した。継手性能の 評価は, 引張剪断強度については $25 \mathrm{~mm}$ 溶接幅に切断した短 冊継手試験片, 剥離強度についてはその短冊継手試験片を溶 接端部から $10 \mathrm{~mm}$ 離れた部分で直角に折り曲げた試験片を用 いて，単位溶接長当たりの破断応力にて評価した。その結果， 継手強度 (引張剪断, 剥離) は新開発シース成分ワイヤが最 も高く, 次いでJIS A4000系ワイヤ, JIS A5000系ワイヤの順 となった。

接合部断面のマクロ観察および接合界面に生成したIMC 層の光学顕微鏡観察の結果を図5に示す。JIS A5000系ワイヤ のIMC層厚は今回の比較の中で最も厚く, またアルミニウム 溶接金属内に針柱形状のものも観察された。一方, JIS A4000 系ワイヤならびに新開発シース成分ワイヤによるIMC層厚 は全体にわたり薄く，とくに新開発シース成分ワイヤは最も 薄く分布していることが確認できた。

一方，フラックスの最適化では， ろう付用の Al-FCWにも 用いられている一般的なノコロックのほかに, 数種類のフ ラックスを準備した。フラックスの選定には, アルミニウム 酸化皮膜の融解性があり, 置換めっき反応や高融点物質生成 がなく，耐食性に影響しない物質とし，かつ Al-FCWへの充 填供給性も考慮した結果, 表 2 に示すフッ化アルミカリウム 化合物をベースとし，フッ化アルミ化合物またはフッ化セシ ウムの混合とした。さらに, 前述の新開発シース材の適用, フラックス充填率の適正化を図り，Al-FCWを試作した。

その試作 Al-FCWを用いて, 前述のシース適正化と同様の
方法で継手を作成し，継手性能を評価した。その結果，A3， A4 はまったく接合せず，A1，A2，B2 は引張剪断強度がほぼ 同等で, 剥離強度は高い順から $\mathrm{B} 2>>\mathrm{A} 1>\mathrm{A} 2$ となった。 $\mathrm{B} 2$ では界面剥離破断をせずアルミニウム合金側で破断，との良 好な結果を得た。一方で，ミグブレーズ溶接による同検証の 結果では，剥離強度が最も高いのはA2 となった。

以上の検証から，レーザブレーズ溶接ならびにミグブレー ズ溶接によるアルミニウム合金/鋼の異種金属接合に適した 新開発の Al-FCWのコンセプトが明確になった。図6には, レーザブレーズ溶接にて得られた接合部の外観を示す。特に ビード外観の改善が顕著で, 新開発の Al-FCWがろう付用の Al-FCW りも安定した溶接部を呈している。本ワイヤはナ イス株式会社の協力を得て実用化も完了した。

本開発でのアルミニウム合金材と鋼板との異種金属接合継 手の継手性能と接合界面のIMC層厚との関係を整理した結 果を図7に示す。本開発の Al-FCWを用いることで, IMC 層 成長の抑制効果が高まり，IMC層厚をより薄く制御できる。 その結果として, 脆いIMCの成長が界面全域にわたり抑制さ れ, 継手性能, 特に剥離強度が改善したと考えられる。

フラックスのIMC抑制の作用については, 現段階では未だ 推定の域を脱しないが, 元来保有する表面洗浄効果により, アルミニウム側だけでなく鉄側の表面皮膜にも影響を及ぼし た可能性があることや，今回添加した CsFが6000系（Al-Mg$\mathrm{Si}$ 系) 酸化皮膜における対 $\mathrm{Mg}$ フラックスとして有効であっ たこと，などが想像される。

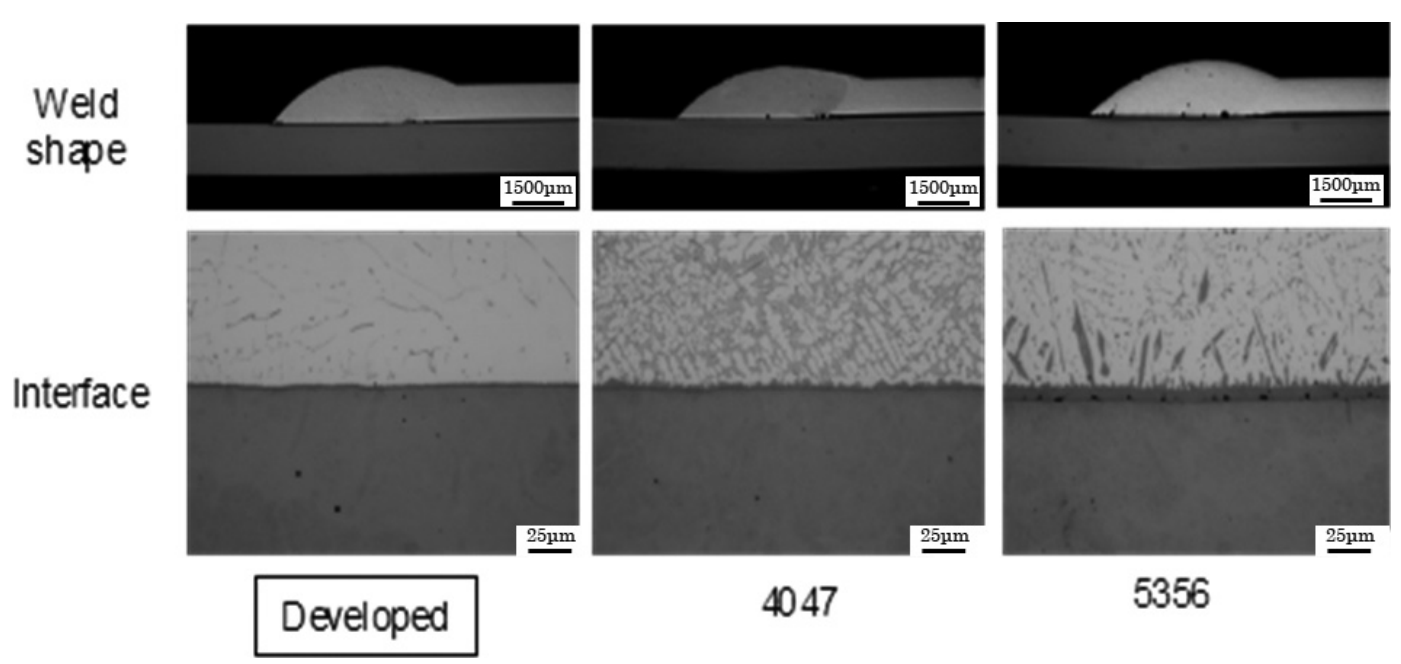

図5レーザブレーズ溶接部の断面形状および界面の比較 ${ }^{9)}$

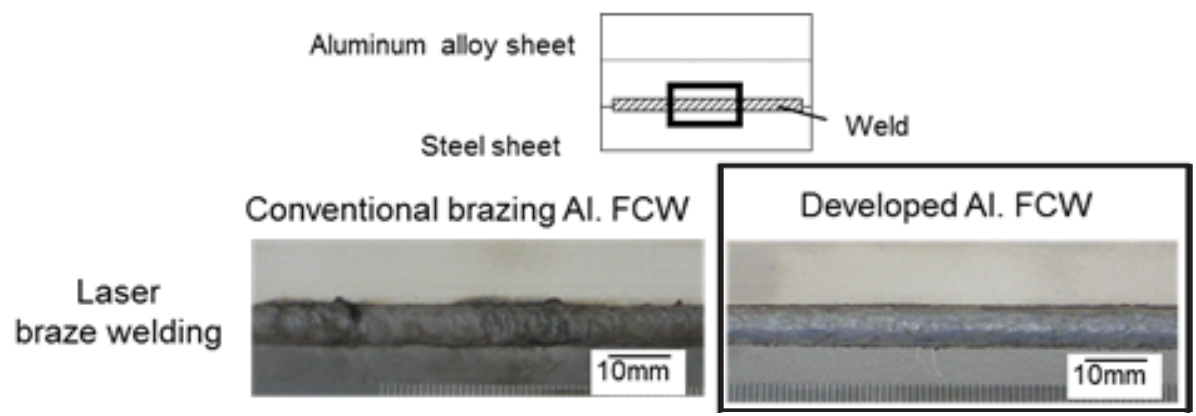

図6 ブレーズ溶接部外観 ${ }^{9)}$ 


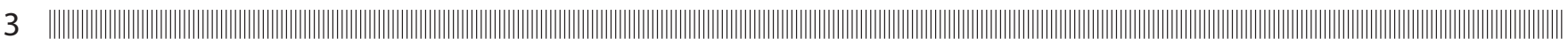

表2 フラックス配合 $(\text { 目標值 })^{9)}$

\begin{tabular}{c|c|c|c}
\hline \hline \multirow{2}{*}{$\begin{array}{c}\text { Al-FCW } \\
\text { 種類 }\end{array}$} & \multicolumn{3}{|c}{ フラックス配合比率 } \\
\cline { 2 - 4 }$(\mathrm{mass} \%)$
\end{tabular}

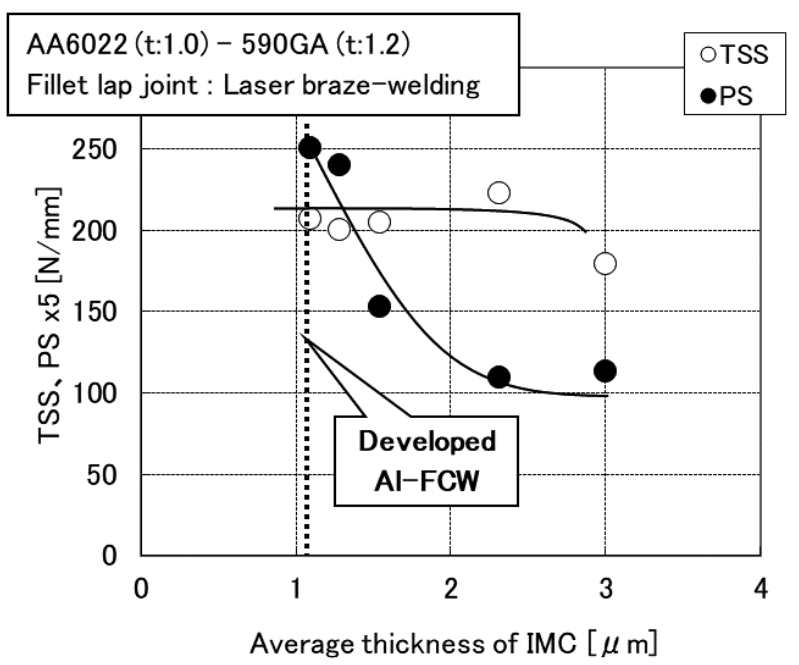

図7 界面 IMC 層厚と継手性能の関係 ${ }^{9}$

\section{4 レーザ異材圧接}

2 枚の A6061 と SPCCの薄板（幅 $12 \mathrm{~mm}$ ）を圧接ローラで押 さえながら，その接合面にYAGレーザを10〜90 Hzでスキャン 照射して面接合する方法が試みられている。レーザ圧接装置 の概略を図 $8^{10}$ に示す。この方法でも，両金属の溶融を少なく した場合, IMC層厚さを薄くでき, 良好な試験片では, 引張荷 重1〜1.6 kNでアルミニウム母材破断をする結果が得られてい る。一方, 剥離試験では，(1)接合界面で剥離が起こり，(2)剥 離強度は比較的低いこと, (3)その剥離面には $\mathrm{FeO}$ が生成して
おり，(4) $\mathrm{FeO}$ はレーザ照射位置を鋼側にずらすと増加するこ と, そして(5)剥離強度は溶接部のシールド状態の改良と圧接 強度の増加により増加できることなどが確認されている。こ の方法でも，溶接部のシールド状態が重要であり，接合中の 継手界面を $\mathrm{Ar}$ ガス雾囲気で覆い，接合中の酸化を防止する必 要がある。な扔,アルミニウム合金と亜鉛めっき鋼板では, 膜 状の IMC 層の生成を防止することによって高引張強度・高剥 離強度の継手を製作できることが明らかにされている ${ }^{11,12) 。 ~}$

\section{5.おわりに}

レーザ溶接を用いたマルチマテリアル接合への検討は，発 振方法，ビームモード，マルチ化などレーザ技術の進化に伴 い，継続的に検討されている。レーザが得意とする高速度加 工，低入熱，瞬発性，リモート制御などを活かした接合技術 が進化していくこと，また，本技術が自動車やそれ以外の分 野に扔いて, 素材選択の幅を広げ, 各材料のもつ特長を最大 限引き出す構造の創出に貢献できることを期待したい。

\section{参 考 文 献}

1) 今村美速：軽金属, 66 (2016), 552-559.

2) 片山聖二 : 軽金属, 62 (2012), 75-83.

3) 三瓶和久：レーザ加工学会誌， 16-1 (2009)， 8-15.

4) 宋 宇絃, 才田一幸, 安藤彰芳, 西本和俊: 溶接学会論文集, 22 (2004)，315-322

5) 才田一幸, 大西春樹, 西本和俊：溶接学会論文集，26(2008), 235-241.

6) 片山聖二 : レーザー研究, 38 (2010)， 594-602.

7) F. Wagner, I. Zerner, M. Kreimeyer, T. Seefeld and G. Sepold: Proc. ICALEO 2001, Section C (2001), 1301.

8) 小椋 智, 祢津俊介, 池 和薰, 才田一幸: 溶接学会論文集, 36 (2018)，247-252

9) 松本 剛, 笹部誠二, 岩井正敏, 杵㴊雅男：自動車技術会論文 集, 42 (2011)，591-596

10) 西本浩司, 奥本良博, 原野智哉, 安宅 健, 藤井洋郎, 片山聖 二：溶接学会論文集， 25(2007)，436-442.

11) 西本浩司, 奥本良博, 原野智哉, 安宅 健, 藤井洋郎, 片山聖 二：溶接学会論文集, 26(2008)，181。

12) 西本浩司, 安宅 健, 藤井洋朗, 片山聖二 : 第63回レーザ加工 学会講演論文集，（2005），133.

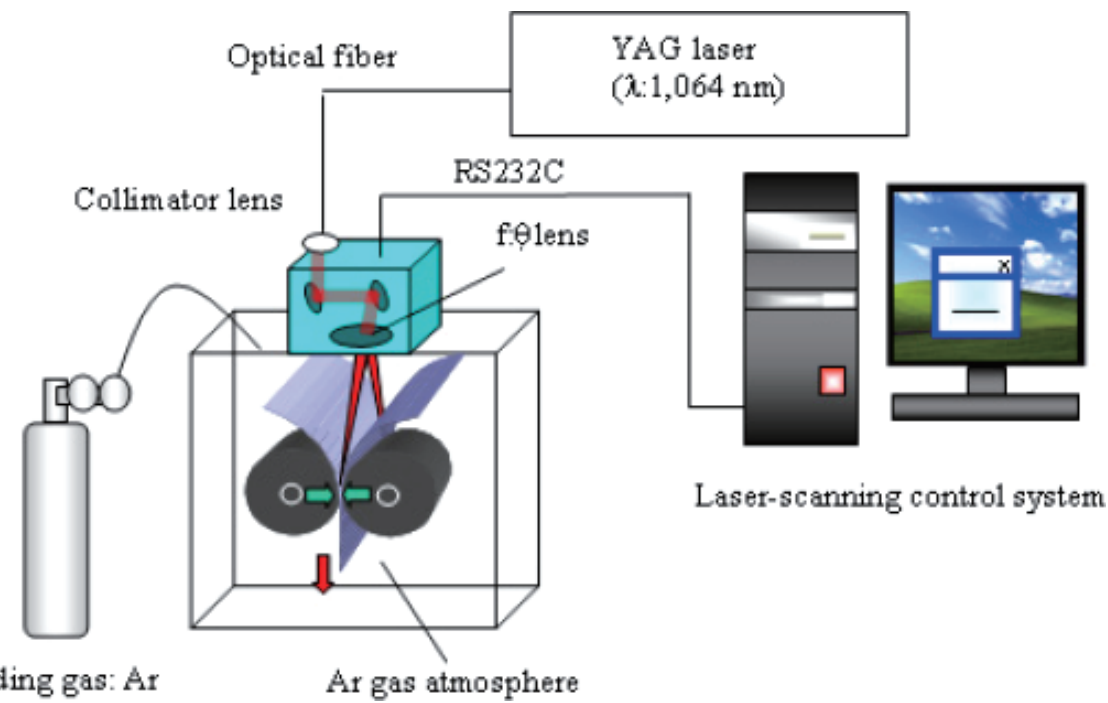

Shielding gas: Ar

Ar gas atmosphere

図8レーザ圧接装置の概略 ${ }^{10)}$ 